\title{
STUDIES ON NORMAL AND LEUKEMIC LEUKOCYTES. V. PYRIDINE NUCLEOTIDE TRANSHYDROGENASES *
}

\author{
By ROBERT SILBER, $\dagger$ F. M. HUENNEKENS, \\ TECHNICAL ASSISTANCE OF MARGARET ALBRECHT
}

\author{
(From the Department of Biochemistry, University of Washington, and King County Central \\ Blood Bank, Seattle, Wash.)
}

(Submitted for publication May 31, 1962; accepted August 16, 1963)

Enzymatic transhydrogenation reactions involving pyridine nucleotides have been described in bacteria (2), beef heart (3), rat and rabbit tissues (4), human placenta (5), and spinach (6). TD transhydrogenase ${ }^{1}$ catalyzes a reaction between TPNH and DPN, as shown in Equation 1, and DD transhydrogenase catalyzes a similar reaction between the oxidized and reduced forms of $\mathrm{DPN}^{2}$ (Equation 2).

TD transhydrogenase

$$
\mathrm{TPNH}+\mathrm{DPN} \rightleftharpoons \mathrm{TPN}+\mathrm{DPNH}
$$

DD transhydrogenase

$\mathrm{DPNH}+\mathrm{DPN}^{*} \rightleftharpoons \mathrm{DPN}+\mathrm{DPNH}^{*}[2]$

The function of these enzymes in vivo is not yet entirely clear, but the TD transhydrogenase may link TPNH to the mitochondrial electron transport system that oxidizes DPNH via molecular oxygen. The DD enzyme, alternatively, may function in the equilibration of free and mitochondrial-bound DPN (3). Hormonal influence on transhydrogenase reactions has been noted by Villee (5), who described the stimulation of a placental TD transhydrogenase by $17-\beta$-estradiol, and by Ball and Cooper (7), who demonstrated the inhibition of a TD transhydrogenase by thyroid hormones.

* This investigation was supported by a grant (P-203) from the American Cancer Society. A preliminary report on this work has appeared elsewhere (1).

$\dagger$ Special fellow of the National Cancer Institute. Present address: Department of Medicine, New York University School of Medicine, New York, N. Y.

$\ddagger$ Present address: Division of Biochemistry, Scripps Clinic and Research Foundation, La Jolla, Calif.

1 Abbreviations: TD and DD, TPNH-DPN transhydrogenase and DPNH-DPN transhydrogenase; DPN and TPN, di- and triphosphopyridine nucleotide; DPNH and TPNH, reduced DPN and TPN; $p \mathrm{CMB}, p$-chloromercuribenzoate; and EDTA, ethylenediaminetetraacetate.

2 The asterisk in Equation 2 indicates a labeled DPN molecule or a DPN analogue to distinguish between the two components.
A previous study from this laboratory (8) on the pyridine nucleotides of human leukocytes revealed a marked elevation of the DPN content of leukemic cells. Because of this finding, a further examination has been made of various enzymes responsible for the interconversion of pyridine nucleotides. The present report describes the identification, characterization, and levels of the two pyridine nucleotide transhydrogenases in the leukocytes of normal subjects and various leukemia patients.

\section{METHODS}

The following materials were used: DPNH, TPNH. and protamine sulfate; ${ }^{3}$ 3-acetylpyridine-DPN, 3-pyridine aldehyde-DPN, 3-acetylpyridine-deamino-DPN, and thionicotinamide-DPN; 4 EDTA; ${ }^{5}$ thyroxine and $3^{\prime} 5^{\prime}$ triiodothyronine ; ${ }^{6}$ 17- $\beta$-estradiol, diethylstilbesterol, and androsterone ; ${ }^{7}$ and 3-acetylpyridine-TP N. ${ }^{8}$

Clinical material for this study was selected according to the criteria used in the preceding paper (9). In general, cells from leukemia patients were obtained before treatment, except that two of the chronic myelocytic leukemia patients were being treated with busulfan and four of the chronic lymphocytic leukemia patients were receiving chlorambucil at the time of sampling. The leukocyte counts and enzyme levels of these treated patients, however, were comparable to those of untreated patients in the same clinical categories, and the data are included, therefore, in this paper. Leukocytes were isolated from whole blood by the procedure described previously $(8,9)$. Enzyme assays were performed on cell lysates prepared as follows: The isolated leukocytes were

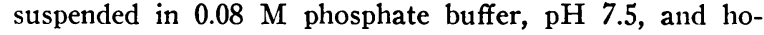
mogenized for 3 minutes at $45,000 \mathrm{rpm}$ in a Virtis " 45 " homogenizer (4- to $15-\mathrm{ml}$ cup). The homogenate was centrifuged for 15 minutes at $10,900 \times g$ in an International refrigerated centrifuge, model PR-2, and the

${ }^{3}$ Sigma Chemical Co., St. Louis, Mo.

4 Pabst Laboratories, Milwaukee, Wis.

5 J. T. Baker Chemical Co., Phillipsburg, N. J.

${ }^{6}$ California Corporation for Biochemical Research, Los Angeles, Calif.

${ }^{7}$ Mann Research Laboratories, Inc., New York, N. Y.

8 Generously supplied by Dr. N. O. Kaplan. 
supernatant fraction was dialyzed for 16 hours at $4^{\circ} \mathrm{C}$ against $0.05 \mathrm{M}$ potassium phosphate buffer, $\mathrm{pH} 7.5$, containing $0.005 \mathrm{M}$ EDTA. Any precipitate resulting from dialysis was removed by centrifugation at $10,900 \times g$ for 15 minutes. Protein concentration in the dialyzed supernatant fraction was determined with the biuret reagent.

Enzyme assays. Transhydrogenase reactions were carried out at $25^{\circ} \mathrm{C}$ according to the procedures of Stein, Kaplan, and Ciotti (4). For the assay of DD transhydrogenase, the reaction mixture contained $100 \mu$ moles of potassium phosphate buffer, $\mathrm{pH} 7.5,1.5 \mu$ moles of sodium cyanide, $0.2 \mu$ mole of DPNH, $0.2 \mu$ mole of 3-acetylpyridine-DPN, and the enzyme ( 1 to $3 \mathrm{mg}$ of protein) in a total volume of $1.0 \mathrm{ml}$. For the assay of TD transhydrogenase, the components were the same except that $\mathrm{pH} 6.5$ phosphate buffer was used, TPNH was substituted for $\mathrm{DPNH}$, and $10 \mu$ moles of EDTA was added. In both reactions, the increase in absorbancy at $375 \mathrm{~m} \mu$ was determined over a 5-minute period and corrected for blank reactions in which $a$ ) the pyridine nucleotide analogue was omitted and $b$ ) the reduced pyridine nucleotide was omitted. The control reactions were less than $10 \%$ of the complete reaction. A millimolar extinction coefficient of 5.1 was used to calculate concentration changes in the above reactions (4).

Purification of leukocyte DD transhydrogenasc. A leukocyte homogenate was dialyzed for 16 hours against $0.05 \mathrm{M}$ potassium phosphate, $\mathrm{pH} 7.5$, containing $0.005 \mathrm{M}$ EDTA, to remove endogenous substrates. One vol of $2 \%$ protamine sulfate was added to the dialyzed homogenate, and the precipitate was removed by centrifugation. The supernatant fluid was fractionated with ammonium sulfate at $4^{\circ} \mathrm{C}$ by the addition of $24.3 \mathrm{~g}$ of ammonium sulfate per $100 \mathrm{ml}$ of solution. After centrifugation, the precipitate ( 0 to $40 \%$ fraction) was discarded, and additional ammonium sulfate ( $24.5 \mathrm{~g}$ per $100 \mathrm{ml}$ of solution)

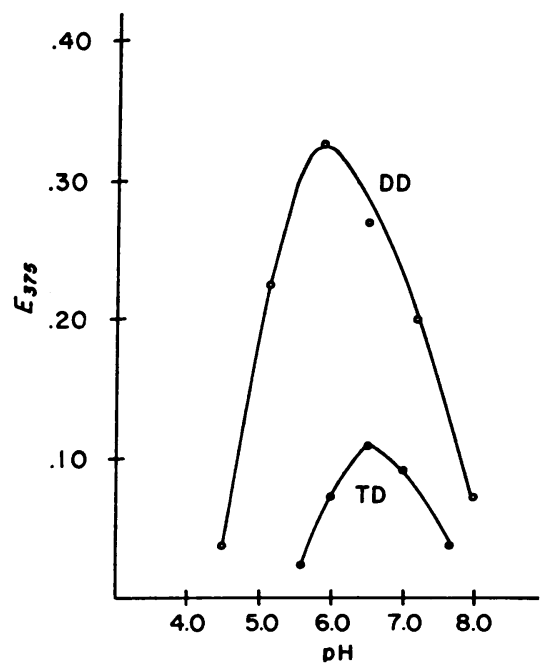

Fig. 1. PH-Activity CURVES for LeUkocyte DPNHDPN (DD) AND TPNH-DPN (TD) TRANSHYDROGENASES.
TABLE I

Effect of mono- and dithiol compounds on the inhibition of transhydrogenases by $\mathrm{Cd}^{++}$and $p$-chloromercuribenzoate $(p C M B) *$

\begin{tabular}{|c|c|c|}
\hline \multirow[b]{2}{*}{ System } & \multicolumn{2}{|c|}{ Activity $\left(\Delta \mathrm{E}_{\mathbf{3 7}}\right)$} \\
\hline & $\mathrm{DD}$ & TD \\
\hline Control & 0.210 & 0.100 \\
\hline $\mathrm{Cd}^{++}\left(5 \times 10^{-4} \mathrm{M}\right)$ & 0.080 & 0.100 \\
\hline $\begin{array}{l}\mathrm{Cd}^{++} \text {followed by 2,3-dimercapto- } \\
\text { 1-propanol }\left(1 \times 10^{-3} \mathrm{M}\right)\end{array}$ & 0.200 & \\
\hline $\begin{array}{l}\mathrm{Cd}^{++} \text {followed by glutathione } \\
\left(5 \times 10^{-3} \mathrm{M}\right)\end{array}$ & 0.105 & \\
\hline $\mathrm{Cd}^{++}$followed by cysteine $\left(2 \times 10^{-3} \mathrm{M}\right)$ & 0.095 & \\
\hline$p \mathrm{CMB}\left(5 \times 10^{-4} \mathrm{M}\right)$ & 0.100 & 0.015 \\
\hline$p$ CMB followed by cysteine $\left(2 \times 10^{-3} \mathrm{M}\right)$ & 0.180 & 0.090 \\
\hline
\end{tabular}

* Enzyme and pyridine nucleotide were preincubated at $25^{\circ}$ with $\mathrm{Cd}^{++}$or $p C M B$ for 5 minutes. The thiol compounds were then added, and after a second incubation period of 5 minutes, the reaction was started by the addition of 3-acetylpyridine-DPN. $\Delta \mathrm{E}_{375}$ refers to the change in absorbancy at $375 \mathrm{~m} \mu$ over a 5 -minute period. DD $=$ DPNH-DPN transhydrogenase, and TD $=$ TPNHDPN transhydrogenase.

was added to the supernatant fluid. The resulting precipitate ( 40 to $75 \%$ fraction) contained the DD transhydrogenase and was resuspended in $0.05 \mathrm{M}$ phosphate buffer, $\mathrm{pH}$ 7.5. The mixture was dialyzed according to the above procedure to remove ammonium sulfate, and an acetone fractionation was carried out at $-20^{\circ} \mathrm{C}$ (6). The fraction that precipitated between 35 to $75 \%$ acetone

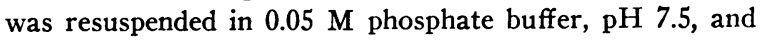
dialyzed. The above procedure results in a DD transhydrogenase purified four times relative to the original homogenate and free of TD transhydrogenase. Studies on the latter enzyme were performed with the initial homogenate.

\section{RESULTS}

Characterization of $D D$ and TD transhydrogenases. The effect of $\mathrm{pH}$ on the activities of both transhydrogenases is shown in Figure 1. The $\mathrm{pH}$ optima for the two enzymes are quite similar, i.e., $\mathrm{pH} 5.8$ for the DD transhydrogenase and $\mathrm{pH} 6.3$ for the TD enzyme, but the relative activity of the DD enzyme is about three times greater at the optimum.

The Michaelis constants for the substrates of the leukocyte transhydrogenases were determined by the conventional Lineweaver-Burk plots-for the DD enzyme, $\mathrm{K}_{\mathrm{m}}=5 \times 10^{-5} \mathrm{M}$ and $7 \times 10^{-5}$ $\mathrm{M}$, respectively, for DPNH and 3-acetylpyridineDPN ; for the TD enzyme, $K_{m}=2 \times 10^{-4} \mathrm{M}$ and 
TABLE II

Reactivity of transhydrogenase enzymes with pyridine nucleotide analogues

\begin{tabular}{crr}
\hline \hline & \multicolumn{2}{c}{ Relative rate* } \\
\cline { 2 - 3 } Analogue & DD & TD \\
\hline 3-Acetylpyridine-DPN & 100 & 100 \\
3-Acetylpyridine-deamino-DPN & 10 & 15 \\
3-Pyridinealdehyde-DPN & 43 & 20 \\
3-Acetylpyridine-TPN & 0 & 0 \\
Thionicotinamide-DPN & 140 & 5
\end{tabular}

* The rates of DD and TD transhydrogenase reactions ith 3-acetylpyridine-DPN were set arbitrarily at 100 . The following wavelengths were used to follow the reactions: $375 \mathrm{~m} \mu$ for 3-acetylpyridine-DPN, 3-acetylpyridine-deamino-DPN, and 3-acetylpyridine-TPN; 365 $\mathrm{m} \mu$ for 3-pyridinealdehyde-DPN; and $400 \mathrm{~m} \mu$ for thionicotinamide-DPN.

$4 \times 10^{-4} \mathrm{M}$, respectively, for TPNH and 3-acetylpyridine-DPN.

A study of the effect of metal ions (at $5 \times 10^{-4}$ $\mathrm{M}$ ) on the two transhydrogenases indicated that, although $\mathrm{Ca}^{++}, \mathrm{Mg}^{++}, \mathrm{Mn}^{++}$, and $\mathrm{Ba}^{++}$do not alter the activity of either enzyme, $\mathrm{Hg}^{++}$inhibits the DD and TD transhydrogenases 30 and $50 \%$, respectively. At $5 \times 10^{-4} \mathrm{M}, \mathrm{Cd}^{++}$shows selective inhibition $(62 \%)$ of DD transhydrogenase, but has no appreciable effect on the TD enzyme (Table I). The inhibition of DD transhydrogenase by $\mathrm{Cd}^{++}$was reversed by the dithiol, 2,3-dimercapto1-propanol, whereas the monothiols, cysteine and glutathione, were ineffective even when present at a concentration five times greater than that of the dithiol. Both the DD and TD enzymes were inhibited about $50 \%$ by $p C M B$ at $5 \times 10^{-4} \mathrm{M}$, and in both cases, the inhibition could be reversed by the addition of cysteine.

The results of experiments concerned with the effect of certain hormones on the leukocyte DD and TD transhydrogenases showed that the latter enzyme was inhibited about $30 \%$ by thyroid hor- mones (1-thyroxine and $3^{\prime}, 5^{\prime}$-triiodothyronine) at a concentration of $10^{-4} \mathrm{M}$, whereas the activity of the DD enzyme was not altered under these conditions. On the other hand, neither of the enzymes was affected by estrogens or androgens, such as $17-\beta$-estradiol ( $3 \mu \mathrm{g}$ per $\mathrm{ml}$ ), a commercial preparation (Premarin) of conjugated estrogens (30 $\mu \mathrm{g}$ per $\mathrm{ml})$, diethylstilbestrol $\left(10^{-4} \mathrm{M}\right)$, and androsterone $\left(10^{-4} \mathrm{M}\right)$.

The relative activities of the leukocyte DD and TD transhydrogenases were studied with several pyridine nucleotide analogues that replaced DPN and $\mathrm{DPN}, *$ respectively, as the oxidants in Reactions 1 and 2 . The analogues differed from DPN in terms of the substituent groups at the 3 position of the pyridine ring or at the 6 position of the adenine moiety. The data for the activities of these analogues with the two transhydrogenases are presented in Table II. When the activity with 3 -acetylpyridine-DPN is set arbitrarily at 100 , decreased rates in both enzyme systems were noted when the analogue was changed by 1 ) deamination of the adenine, 2) replacement of the acetyl group with an aldehyde, or 3) addition of a third phosphate to give 3-acetylpyridine-TPN. Replacement of the 3-acetyl group by a thioamide group, as in thionicotinamide-DPN, however, enhanced the rate of the DD enzyme, but caused a decrease in the acivity of the TD enzyme.

Levels of DD and TD transhydrogenases in normal and leukemic leukocytes. The levels of both transhydrogenase enzymes were determined in 25 normal subjects and in 25 patients with leukemia (Table III). ${ }^{9}$ The DD transhydrogenase

9 Using a different assay than the one employed here, Evans and Karnovsky (10) were unable to detect the presence of TD transhydrogenase in polymorphonuclear leukocytes from peritoneal exudates of guinea pigs, although a pyridine nucleotide oxidase was found with a

TABLE III

Levels of transhydrogenases in normal and leukemic leukocytes

\begin{tabular}{|c|c|c|c|}
\hline \multirow[b]{2}{*}{ Cell type } & \multirow[b]{2}{*}{ No. of subjects } & \multicolumn{2}{|c|}{ Transhydrogenase activity } \\
\hline & & DD & TD \\
\hline & & \multicolumn{2}{|c|}{ mumoles $/ \mathrm{hr} / \mathrm{mg}$ protein } \\
\hline Normal & 25 & $178 \pm 12(90-280)^{*}$ & $37 \pm 6(20-80)$ \\
\hline Chronic myelocytic leukemia & 8 & $286 \pm 46(150-430)$ & $72 \pm 20(30-200)$ \\
\hline Chronic lymphocytic leukemia & 10 & $287 \pm 46(100-550)$ & $161 \pm 46(59-290)$ \\
\hline Acute leukemia & 7 & $362 \pm 98(130-600)$ & $150 \pm 32(49-220)$ \\
\hline
\end{tabular}

* Mean $\pm \mathrm{SE}$. The range for each group is indicated in parentheses. 
activity is about 2 to 4 times higher than that of the TD enzyme in each of the cell types. The mean level of the DD transhydrogenase in leukemic cells is somewhat higher than in normal leukocytes, but there is considerable overlap between the ranges, and the difference between the means is of a relatively low degree of statistical significance $(p=0.05$ to 0.1$)$. On the other hand, the mean level of TD transhydrogenase is 3 to 4 times greater than normal in the cells of chronic lymphocytic leukemia and acute leukemia; these differences are significant at the $1 \%$ level. Even the TD value for chronic myelocytic leukemia is increased above normal in a statistically significant manner $(\mathrm{p}<0.05)$. The $\mathrm{pH}$ curves and $\mathrm{Mi}$ chaelis constants of the transhydrogenases from leukemic cells were identical with those of normal leukocytes, thus validating the use of the same assay systems given in the methods section for determining the levels of these enzymes in both normal and leukemic cells.

\section{DISCUSSION}

In general, properties of the leukocyte transhydrogenases, such as the Michaelis constants, inhibition by $\mathrm{Hg}^{++}$and $\mathrm{Cd}^{++}$, and reactivity toward pyridine nucleotide analogues, are similar to those of the transhydrogenases from other sources. Since the $\mathrm{Cd}^{++}$inhibition of DD transhydrogenase can be reversed by dithiols, but not by monothiols, it is likely that vicinal dithiol groups are involved in the mechanism of action of this enzyme, which thus resembles its counterpart in beef heart mitochondria (3). The leukocyte enzymes are unique, however, among transhydrogenases insofar as their $\mathrm{pH}$ optima are about $2 \mathrm{pH} \mathrm{U}$ lower than usual.

Evidence that two separate enzymes are involved in Reactions 1 and 2 is provided by the following observations: 1) TD activity is lost during the purification procedure for the DD activity; 2) $\mathrm{Cd}^{++}$at $5 \times 10^{-4} \mathrm{M}$ inhibits the DD activity, but does not alter TD activity; 3) DD transhydrogenase is more active with thionicotinamide-DPN as a substrate than with 3-acetylpyridine-DPN, whereas the converse relationship obtains for the TD enzyme; and 4) thyroid hormones inhibit TD transhydrogenase, but not DD transhydrogenase.

similar $\mathrm{pH}$ optimum and $\mathrm{K}_{\mathbf{M}}$ values like those of the transhydrogenase described above.
Although various transhydrogenases have been reported to be affected by thyroid hormones (7) and by certain steroid hormones (5), the leukocyte enzymes are relatively insensitive to these agents. The TD transhydrogenase is partially inhibited by thyroxine or triiodothyronine, but only when these hormones are present at $10^{-4} \mathrm{M}$, and the in vivo significance of this finding is doubtful. None of the steroid hormones tested had any effect on either leukocyte transhydrogenase activity.

The finding that the level of TD transhydrogenase is markedly elevated in the leukemic leukocyte represents a second quantitative difference from normal cells encountered in the general area of pyridine nucleotide metabolism. Thus, there appears to be a general relationship in let1kocytes between TD transhydrogenase levels and the DPN levels (8), inasmuch as the highest level of the enzyme is found in acute and chronic lymphocytic leukemic cells that also contain the highest concentration of DPN. Conversely, normal leukocytes contain the lowest level of both DPN and TD transhydrogenase, whereas cells from patients with chronic myelocytic leukemia are intermediate in both respects. Because of the possible relationship of DPN to the altered respiratory patterns of tumor tissue (11) and the suggested role of these coenzymes in the control of metabolic pathways, further investigation along this line seems indicated.

\section{SUM MARY}

1)Leukocytes contain a TD transhydrogenase $(\mathrm{TPNH}+\mathrm{DPN} \rightleftharpoons \mathrm{TPN}+\mathrm{DPNH})$ and a DD transhydrogenase $\left(\mathrm{DPNH}+\mathrm{DPN}^{*} \rightleftharpoons \mathrm{DPN}+\right.$ $\left.\mathrm{DPNH}^{*}\right){ }^{2}$

2) The $\mathrm{pH}$ optima for the $\mathrm{DD}$ and TD transhydrogenases are 5.8 and 6.3 , respectively. At their optima, the relative activity of the DD enzyme is about 3 times that of the TD enzyme.

3) Both transhydrogenases are inhibited about $50 \%$ by $p$-chloromercuribenzoate at $5 \times 10^{-4} \mathrm{M}$, and the inhibitions are reversed by the addition of thiols. $\mathrm{Cd}^{++}$at $5 \times 10^{-4} \mathrm{M}$ inhibits the DD enzyme about $65 \%$, but does not affect the TD enzyme; this inhibition is reversed by dithiols but not by monothiols.

4) Thyroxine and triiodothyronine at $10^{-4} \mathrm{M}$ inhibit the TD enzyme by about $30 \%$, but do not 
affect the DD enzyme. Steroid hormones do not affect either transhydrogenase.

5) Levels of the two transhydrogenases have been determined in 25 normal subjects and in 25 patients with leukemia. The level of the DD enzyme is 2 to 4 times higher than that of the TD enzyme in both normal and leukemic cells. The level of the TD transhydrogenase is 3 to 4 times higher than normal in acute and chronic lymphocytic leukemic cells and slightly higher than normal in chronic myelocytic cells. The level of the DD enzyme is elevated slightly above normal in the leukemic cells.

\section{ACKNOWLEDGMENT}

The authors are indebted to Drs. J. R. Czajkowski, D. H. Coleman, Q. B. DeMarsh, and P. A. Ragen for providing us with blood specimens.

\section{REFERENCES}

1. Silber, R., F. M. Huennekens, and B. W. Gabrio. Pyridine nucleotide transhydrogenases in normal and leukemic leukocytes. Clin. Res. 1962, 10, 109.

2. Colowick, S. P., N. O. Kaplan, E. F. Neufeld, and M. M. Ciotti. Pyridine nucleotide transhydrogenase I. Indirect evidence for the reaction and purification of the enzyme. J. biol. Chem. 1952, 195, 95.

3. Kaufman, B., and N. O. Kaplan. Pyridine nucleotide transhydrogenase VIII. Properties of the transhydrogenase reactions of an enzyme complex isolated from beef heart mitochondria. J. biol. Chem. 1961, 236, 2133.

4. Stein, A. M., N. O. Kaplan, and M. M. Ciotti. Pyridine nucleotide transhydrogenase VII. Determination of the reactions with coenzyme analogues in mammalian tissues. J. biol. Chem. 1959, 234, 979.

5. Villee, C. A. The role of steroid hormones in the control of metabolic activity in The Molecular Control of Cellular Activity, John M. Allen, Ed. New York, McGraw-Hill, 1962, p. 297.

6. Keister, D. L., A. San Pietro, and T. E. Stolzenbach. Pyridine nucleotide transhydrogenase from spinach I. Purification and properties. J. biol. Chem. 1960, 235, 2989.

7. Ball, E. G., and O. Cooper. The oxidation of reduced triphosphopyridine nucleotide as mediated by the transhydrogenase reaction and its inhibition by thyroxine. Proc. nat. Acad. Sci. (Wash.) 1957, 43, 357.

8. Silber, R., B. W. Gabrio, and F. M. Huennekens. Studies on normal and leukemic leukocytes III. Pyridine nucleotides. J. clin. Invest. 1962, 41, 230.

9. Bertino, J. R., R. Silber, M. Freeman, A. Alenty, M. Albrecht, B. W. Gabrio, and F. M. Huennekens. Studies on normal and leukemic leukocytes. IV. Tetrahydrofolate-dependent enzyme systems and dihydrofolic reductase. J. clin. Invest. 1963, 42, 1899.

10. Evans, W. H., and M. L. Karnovsky. The biochemical basis of phagocytosis. IV. Some aspects of carbohydrate metabolism during phagocytosis. Biochemistry 1962, 1, 159.

11. Aisenberg, C. The Glycolysis and Respiration of Tumors. New York, Academic Press, 1961, p. 96. 